Marquette University

e-Publications@Marquette

Finance Faculty Research and Publications

Finance, Department of

$4-1-2006$

\title{
The Value of Foreclosed Property
}

Anthony Pennington-Cross

Marquette University, anthony.pennington-cross@marquette.edu

Published version. Journal of Real Estate Research, Vol. 28, No. 2 (April-June 2006): 193-214.

Publisher Link. (C) 2006 American Real Estate Society. Used with permission.

Anthony Pennington-Cross was affiliated with the Federal Reserve Bank of St. Louis at the time of publication. 


\section{The Value of Foreclosed Property}

Author

Anthony Pennington-Cross

Abstract

This paper examines the expected price appreciation of distressed property and compares it to the prevailing metropolitan area appreciation rate. Whether due to individual property or local area heterogeneity in appreciation, the results show that foreclosed property appreciates less than the area average appreciation rate. The magnitude of the deviation is sensitive to loan characteristics, legal restrictions, housing market conditions and marketing time.

\section{Introduction}

If the prices of homogeneous properties differ, arbitrage opportunities arise for opportunistic home-buyers or home-sellers. In efficient markets, arbitrage opportunities quickly dissipate and, thus, competition effectively eliminates price deviations and reinforces the market-clearing price.

With the dissipation of arbitrage opportunities, the value of all identical property should be the same, whether it is being sold by a homeowner or by a lender whose has foreclosed on it. Unfortunately, the heterogeneity and thinness of housing markets can make it difficult to identify the value of a house. Two methods of estimating the value of property dominate both the academic and professional spheres. The first, the hedonic method, relies on the ability to identify and value all the attributes of a house and its location. Using each of these values, the expected price of any home can be estimated. The second method, the repeat sales method, relies on area-wide appreciation rates to update the last available transaction price on the home and determine the expected value of the home.

In contrast to previous literature on the value of foreclosed property, this paper uses the repeat sales approach to estimate the house price appreciation of property where the second transaction used to calculate the appreciation rate is the sale of foreclosed property. These appreciation rates, which will be referred to as foreclosure appreciation rates, are used to determine if this unique pair of repeat transactions (normal property, foreclosed property) appreciate in a systematically different way than a typical pair of repeat transactions (normal property, normal property).

This approach relies primarily on a publicly available repeat sales price index and does not require detailed or timely information about the exact characteristics of 
the property or the location. This should make it much easier and less expensive for lenders to estimate the loss from the sale of foreclosed property. Previous literature has also been limited because of the limited geographic coverage and small sample sizes. In contrast, the sample used in this paper includes more than 12,000 sales of real estate owned (reo) property obtained through foreclosure proceedings and covers all 50 states and the District of Columbia in the United States.

The results indicate that the expected appreciation rates for foreclosed property, which is defined as property that is for sale as real estate owned property in the second of the two observed repeat transactions and normal or typical property in the first of the two observed repeat transactions, ${ }^{1}$ are lower than area appreciation rates. Information on expected appreciation rates on distressed properties can be used by lenders to help determine loss mitigation strategies.

This paper cannot test to see if foreclosure itself causes a decrease in price. Instead, the results are interpreted as being consistent with individual property deviation or location-specific deviation from the area-wide average appreciation rate. The cause of this heterogeneity of appreciation rates may be due to changes in neighborhood characteristics or changes in the characteristics of the property. For example, the neighborhood could suffer from increased crime or a reduction in school quality or the property could be flooded and not be fully repaired.

The remainder of the paper will review earlier estimates of the discount foreclosures sell for, explore potential reasons for deviations in appreciation rates from the mean for foreclosed property, and provide an empirical model to estimate the extent of the deviations.

\section{Estimates of the Foreclosure Discount}

The foreclosure discount refers to the deviation between the expected price or appreciation of typical or average property and the price or appreciation of the foreclosed property. Prior efforts to estimate the discount at which a foreclosed property sells have used very similar approaches-the hedonic model. Exhibit 1 shows that three of the four papers find that the selling price of a foreclosed property is $22 \%$ to $24 \%$ lower. In contrast, consistent with the efficient market theory, the most recent paper, by Carroll, Clauretie and Neill (1997), finds no discount associated with selling a foreclosed property.

Despite these contradictory findings, the papers are very similar to each other in terms of the method of analysis. For example, each estimates a hedonic model expressed as:

$$
\operatorname{Ln}(P)=f(X, F) .
$$


The Value of Foreclosed Property| 195

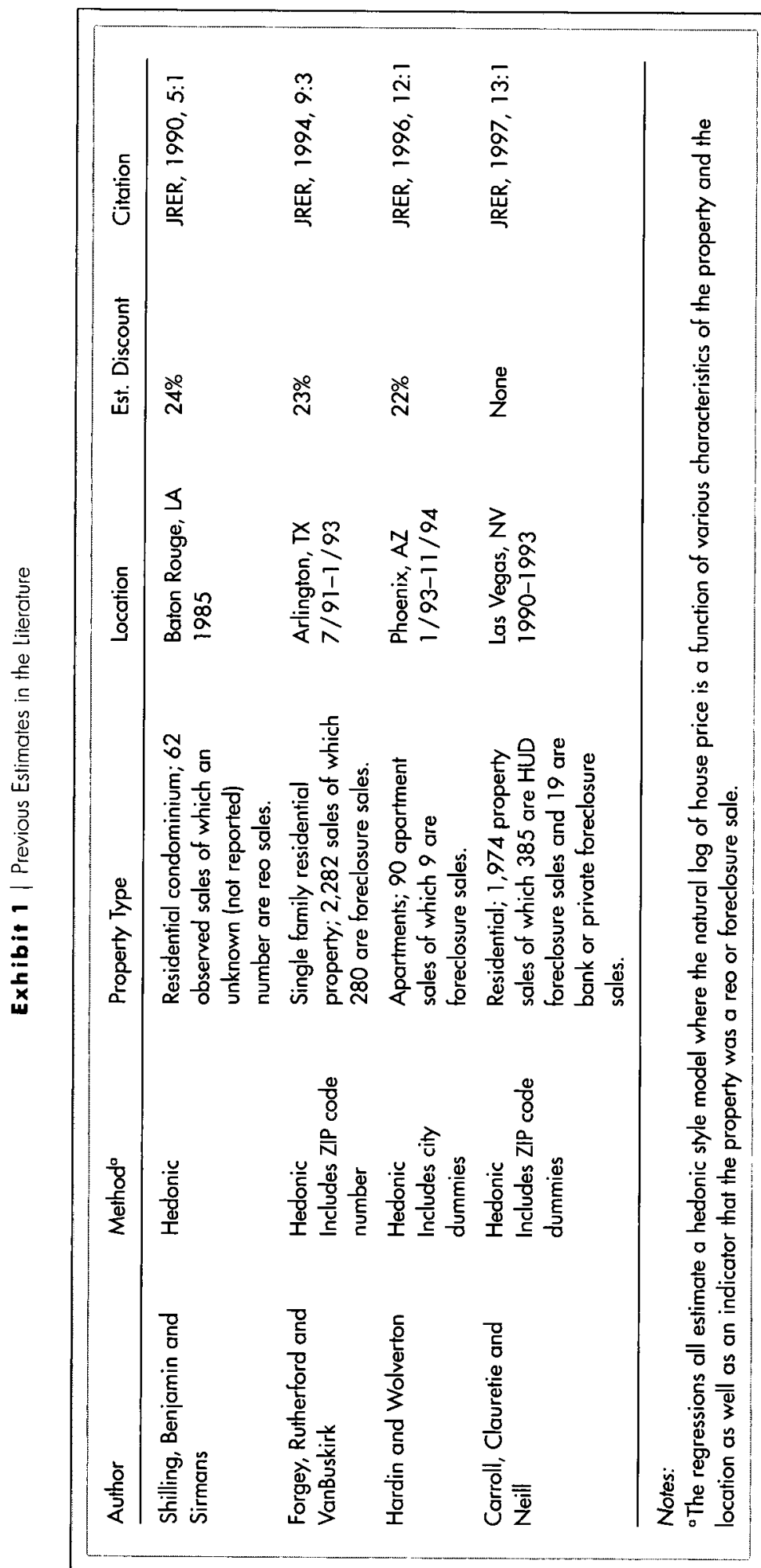

\begin{tabular}{l|l|l} 
JRER & $V \circ I .28$ & No. $2-2006$
\end{tabular} 
Where $P$ is the price of the property, $X$ is a vector of explanatory variables that describe the property and its location, and $F$ indicates if the property is sold as a foreclosure. The estimated coefficient can then be interpreted as an indicator of how much less or more the foreclosed property will sell for.

The first paper, by Shilling, Benjamin and Sirmans (1990) provides the basic approach, which the three other papers follow. They define the dependant variable as the natural $\log$ of the condominium price on a set of explanatory variables designed to describe the property and the location of the property. These characteristics include items such as living area, location near a swimming pool, vaulted ceilings, number of bedrooms, location in the condominium complex (distance to mail room, trash and parking lot), and density. Because hedonic models are sensitive to specification, the vector $X$ should be comprehensive and in the correct functional form. In addition, a unique model is required for each location to identify the marginal contribution and value of each housing and location attribute. Therefore, hedonic models become cumbersome and expensive to maintain for any national lender who is trying to estimate expected sales prices for distressed property.

The remaining papers follow the same approach, but study different property types-condominiums, single family, multifamily (apartment) and residential. Forgey, Rutherford and VanBuskirk (1994) use the ZIP code number to control for location. ${ }^{2}$ Carroll, Clauretie and Neill (1997) instead use ZIP code dummies to control for location. When the ZIP code dummies are included, the foreclosure indicator becomes insignificant for HUD foreclosures. These results emphasize the need for unique models to determine the value of foreclosed property using the hedonic methodology. For example, each city will require its own hedonic model, because it makes little sense to impose the same marginal value of an additional square foot of living space to an apartment in New York City, NY as New Brunswick, NJ even though they are spatially close to each other.

The papers also only focus on one location at a time and suffer from very small sample sizes. For example, Hardin and Wolverton (1996) have 9 observed foreclosure sales and Shilling, Benjamin and Sirmans (1990) do not report how many of the 62 transactions were foreclosures.

An alternative approach is to use publicly available price indexes (see Freddie Mac and the Office of Federal Housing Enterprise Oversight, OFHEO, www.ofheo.gov, for publicly available repeat sales price indexes). Using a price index, the value of any property could be updated to current values by simply using the last available transaction or appraisal price. This would allow full coverage of the U.S. using minimal resources. However, using the index by itself without any adjustment for the impact of selling reo property or foreclosed property may misstate the value of the property if it is true that foreclosed property does sell at a discount. Therefore, it may be necessary to make an adjustment to the expected appreciation rate. The following empirical section details how to estimate and calculate any adjustment needed to the area-wide expected 
appreciation rate. In addition, the repeat sales method will automatically incorporate any changing conditions of the location through time and there is no need to collect detailed information about the property itself or the surrounding location. This approach does assume that the property undergoes typical maintenance and upgrades for foreclosed property. It does not assume that foreclosed property has a typical maintenance history. In fact, any estimates of the discounted appreciation rate will include the typical maintenance shortfall associated with foreclosed properties in addition to any other factors unique to foreclosures. In addition, similar to the hedonic approach, any deviations or heterogeneity in appreciation rates within the defined location will not be captured.

\section{Why Would Foreclosed Property Sell at a Discount?}

Just because a property was foreclosed is not enough to explain why it should sell for less than comparable or nearby property. Surely, market participants are savvy enough to identify under-priced property and make an arbitrage profit. This is especially true for institutional sellers who must have good market knowledge through years of selling distressed property.

One potential explanation for why foreclosed property would appreciate less than its neighbors may simply be that the property has not captured area-wide appreciation. In this view, house price appreciation rates are distributed around a mean appreciation rate and foreclosures tend to be in the tail. This may be due to neighborhood- or property-specific issues. For example, not all neighborhoods appreciate at the same rate because the metropolitan area repeat sales index represents only the average appreciation rate. Some neighborhoods within the metropolitan area may experience rapid appreciation or depreciation due to changes in the characteristics of the neighborhood or changes in preferences for those characteristics. At the property level, events out of control of the homeowner such as an unexpected and uninsured flood or the discovery of a fuel tank in the yard can impact the value of the property. In addition, not all owners will maintain the property with the same vigilance. Therefore, heterogeneity of depreciation rates is to be expected.

When the value of a house is less then the mortgage, then the borrower is in a negative equity position. Ignoring transaction costs and a lender's right of redemption, a ruthless defaulter will default exactly when the property enters a negative equity position. Once other costs, born by the borrower, of default are factored into the decision, then it is necessary for the negative equity position to be larger. While other events, typically referred to as trigger events (such as employment and family structure shocks), can lead to missed payments, it makes financial sense for borrowers to default, instead of prepaying the loan and becoming a renter, if there exists a negative equity position. Therefore, it is likely that many or most of the observed foreclosure sales are loans where the borrower was in a negative equity position. Since homeowners can add more debt through second mortgages or lines of credit, negative equity does not in itself imply lower

\begin{tabular}{l|l|l|l} 
JRER & VOI. 28 & No. $2-2006$
\end{tabular}


house price appreciation rates. But, negative equity and price appreciation should be negatively correlated.

In addition, owners who are at risk of defaulting may spend less on maintaining the property. Supporting this theory, Harding, Miceli and Sirmans (2000) find evidence that borrowers with loan-to-value (LTV) ratios near one spend less on maintenance than other homeowners. This will cause house prices on homes, which have likely already deteriorated in value, to deteriorate even further.

Another argument for why foreclosed property may sell for less is that institutional lenders/sellers are operating under a unique set of incentives that make them more likely to accept below market prices on foreclosure sales. For example, regulatory capital requirements are designed to provide incentives to remove nonperforming assets from balance sheets. In addition, there is some evidence that owning real estate purchased through foreclosures can have impacts on stock prices and credit ratings (Downs, 1992; and Palmer, 1991). Also, each day that a non-performing loan remains on the books the costs increase. For example, the property needs to be maintained while it is vacant. The lender is also not receiving any income from the loan and the loan is tying up funds that could be used to fund other performing assets. To sell a property, the lender must also pay customary fees to an agent who markets the property.

In an efficient thick market, however, the incentives of individual sellers and buyers are irrelevant to the market clearing price. For a homogeneous product with a large and deep market, a single price is available to all buyers and is easily identified. As shown by the literature review, house prices can be thought of as the sum of the value or price of all of its components (location description, physical characteristics, number of bedrooms, etc.). Therefore, large and fairly homogeneous new housing developments make it fairly straight forward to estimate and establish the value of individual attributes and the house as a whole because the market is both deep and thick.

As houses get older, it becomes more difficult to accurately ascertain the market price because they become less homogeneous and it may become harder to observe all the characteristics. For example, attributes of the house can change through time or maintenance of the property can also vary by owner. For example, if a homeowner is in a negative equity position (mortgage value $>$ house value) it may make little sense to incur additional expenses to maintain the property because it will reduce the size of the negative equity and thus the value of the option to default on the mortgage (Harding, Miceli and Sirmans, 2000).

In the housing market, the seller sets an asking price that is used as the starting point for any further negotiation. Before a potential buyer makes a bid and decides to enter negotiation, a physical inspection of the property is typically needed (Arnold, 1999). This implies that it is very difficult to adequately describe the attributes of a house and that homes with the same attributes (location, number of baths, modern electricity, etc.), such as those used in a hedonic model, may 
differ in subtle and important ways that could only be determined after an actual inspection of the property. In sum, it is difficult and costly to determine the attributes associated with individual houses.

The uniqueness and thinness of the housing market leads to bargaining and introduces the characteristics of the product and the characteristics of the seller and buyer, as well as the bargaining skills of the participants in market transaction prices (Harding, Rosenthal and Sirmans 2003). For example, sellers with less equity in the home typically may receive a higher than otherwise expected price. One explanation of this is that homeowners need the equity in their current home to provide a sufficient downpayment on their next purchase (typically a contingent sale) (Genesove and Mayer, 1997). A host of other factors can affect the bargaining position of the seller. For example, there is evidence that "out-ofcountry,", "out-of-state," first time and in-migrate home buyers all pay premiums (Turnbull and Sirmans, 1993; Watkins 1998; and McQueen and Slade, 2003).

\section{Getting from Default to Foreclosure Sale}

It is a long road from a delinquent mortgage to the sale of foreclosed property and there are many other options available to both the lender and borrower. This paper examines the sale of property where the lender has become the owner. This type of property is typically referred to as real estate owned or reo property. A lender can become the owner of a property at any stage during delinquency and foreclosure proceedings. The lender may become the owner of the property through agreement with the homeowner or through forceful eviction. The lender may even purchase the property at an auction or through other public proceedings; however, the purchase of foreclosed property by a lender is not the topic studied in this paper. Instead, this paper examines the sale of reo property and how the appreciation of this property confounds area-wide appreciation rates.

Before a property becomes reo, the lender and homeowner have many other options available to them. For example, the lender can encourage the owners of a home with a delinquent mortgage to sell the home to avoid foreclosure proceedings and the stigma of foreclosure on their credit report. These preforeclosure sales are also referred to as short sales if the selling price of the home is less than the outstanding debt and late fees owed the lender. Often, the lender will agree not to collect the remaining balance in a pre-foreclosure sale. This could be in the best interest of the lender because the costs and time delays of foreclosure are avoided. Indeed, a pre-foreclosure sale is conducted by the owner of the property and therefore looks at least on the surface very similar to a typical sale. Depending on the agreement with the lender, the seller-owner may have incentives to sell the home quickly or slowly. For example, the lender may set a time limit on how long it is willing to wait for the sale to be completed. Or the lender may limit how much of a loss it is willing to absorb. These incentives could lead to higher or lower listings, times on the market and transaction prices than typical.

\begin{tabular}{l|l|l} 
JRER & Vol. 28 & No. $2-2006$
\end{tabular} 
Another option for the lender and borrower is for the borrower to hand over the deed to the property in lieu of foreclosure. Again, the lender avoids going through the foreclosure process, but any liens attached to the title will become the responsibility of the lender. As with a pre-foreclosure sale, the lender typically forgoes the ability to collect on any unpaid principal, interest, taxes, or fees in exchange for the deed. The property is then considered reo and the lender will sell the property in the open market. Once the property becomes reo, the lender must market the property and enter into negotiations with any potential buyers.

Another option available to the lender is to proceed through foreclosure and collect the proceeds from the sale of the property or purchase the property itself. The sale of foreclosed property is conducted under two broad legal regimes: the judicial foreclosure process or the power-of-sale or non-judicial foreclosure process. Put simply, judicial foreclosures involve the state court system; in nonjudicial states, the lender has the power to evict the defaulted borrower and sell the property on its own. Large power-of-sale states include California, Texas and Michigan. In general, foreclosures in judicial states take much longer than nonjudicial foreclosures. However, even within judicial states, the method by which the property is sold varies widely from county to county. For example, the property could be sold at a public auction at an advertised place and location. The property could be also auctioned at "Sheriff Sales," which will typically occur once a month. Other alternatives, which may not be auctions, include attorney sale, court appointed referee sale, or even sale at the court house or at the property itself. There are also a variety of ways that foreclosed property sold in non-judicial foreclosure states are influenced by local legal and customary practices. But typical power-of-sale foreclosure sales include auction sales or trustee sales after an advertising period.

In both regimes (power-of-sale or judicial), the lender has the opportunity to purchase the property with no additional cash outlay at the foreclosure sale. If the lender does this, then the property is considered reo property-the property is now owned by the lender instead of the borrowers. A lender might purchase the property if it believes the auction price is substantially below market value or when the defaulted amount plus other fees (lender total investment) is less than the highest available purchase price. For example, imagine an auction with only one other party and the party offers $\$ 100$ for the property. If the lender decides not to bid $\$ 101$ even though the property value is much higher in some states, the defaulted borrower will have the statutory right to then redeem the property for $\$ 101$ plus late fees, thus regaining ownership. This is one reason why only sensible offers tend to win the auction or bidding and the winning offer should be above the lender's total investment or a sensible redemption value.

Assuming no acceptable bids are put forth, the lender can choose to "win" the auction and purchase the property. ${ }^{3}$ If the lender wins the auction, the property becomes reo property. It is the sale of reo property, whether purchased through a foreclosure sale, a deed in lieu agreement or any other form, that the empirical analysis uses to estimate the foreclosure discount. 


\section{Empirical Test}

The objective of this section is to estimate the magnitude of the foreclosure discount, measured through relative expected appreciation rates, as well as any additional impact caused by the weaker bargaining position of the lender when selling the property. Only the sale of reo property is considered.

Earlier two arguments were presented as to why foreclosed property will appreciate less than the area average a rate. First, foreclosure sales are by definition loans that have defaulted and are therefore likely to have experienced a relative reduction in price. In essence, this argument is simply that the property was unlucky and had a negative shock to its price or that households that default on a loan do not do typical maintenance and therefore the price is lower. Second, when a lender owns property (reo), it is in a weak bargaining position and as a result is willing to accept a lower price to dispose of the property quickly.

The empirical test is set up as:

$$
\Delta=f(\phi, \beta, \psi)
$$

where $\Delta$ is the foreclosure discount defined as the difference between the appreciation rate for the metropolitan area as a whole and the appreciation rate for the house being sold; $\phi$ is the discount associated with foreclosures; $\beta$ is the discount associated with bargaining power during the marketing of the property; and $\psi$ are other factors that could impact the value of the property.

To examine the contributing factors to the foreclosure discount, a stratified random sample of over 12,000 reo sales is used. The sales are taken from metropolitan areas where the repeat sales index was available from two large secondary market institutions. The institutions primarily are involved in the prime market. To help protect the proprietary nature of the data and the identity of the institutions, the sample rates cannot be revealed. In addition, high cost loans, which are defined as loans with interest rates at least 100 basis points above the prevailing prime rate as defined by the Freddie Mac Primary Mortgage Market Survey (PMMS) are over-sampled to insure their representation in the data set. The intent is to provide enough observations of these higher cost and presumably higher risk loans to identify any additional discount. The data include only single-family 30-year fixed-rate mortgages originated from 1995 through 1999. The loan outcome is also only observed until the end of 1999 , thus creating a truncated sample of defaulted loans. To aid interpretation of the results, all continuous variables are mean deleted (the mean equals zero) during estimation.

Exhibit 2 provides the geographic distribution of the loans. It shows that, as expected, California, Florida and Texas are the states with the largest number of

\begin{tabular}{l|l|l} 
JRER & Vol. 28 & No. 2 -2006
\end{tabular}


Exhibit 2 | Geographic Distribution of Loans

\begin{tabular}{|c|c|c|c|c|c|}
\hline State & $\begin{array}{l}\text { Number of } \\
\text { Loans }\end{array}$ & $\begin{array}{l}\text { Percentage } \\
\text { of All Loans }\end{array}$ & Slate & $\begin{array}{l}\text { Number of } \\
\text { Loans }\end{array}$ & $\begin{array}{l}\text { Percentage of } \\
\text { All Loans }\end{array}$ \\
\hline AK & 1 & 0.01 & MT & 6 & 0.05 \\
\hline $\mathrm{Al}$ & 156 & 1.27 & NC & 170 & 1.38 \\
\hline$A R$ & 29 & 0.24 & ND & 4 & 0.03 \\
\hline $\mathrm{AZ}$ & 340 & 2.77 & NE & 10 & 0.08 \\
\hline$C A$ & 2530 & 20.60 & $\mathrm{NH}$ & 10 & 0.08 \\
\hline $\mathrm{CO}$ & 93 & 0.76 & NJ & 195 & 1.59 \\
\hline $\mathrm{CT}$ & 70 & 0.57 & NM & 64 & 0.52 \\
\hline$D C$ & 108 & 0.88 & NV & 270 & 2.20 \\
\hline$D E$ & 13 & 0.11 & NY & 280 & 2.28 \\
\hline $\mathrm{FL}$ & 2622 & 21.35 & $\mathrm{OH}$ & 258 & 2.10 \\
\hline GA & 483 & 3.93 & OK & 68 & 0.55 \\
\hline $\mathrm{HI}$ & 45 & 0.37 & OR & 75 & 0.61 \\
\hline IA & 57 & 0.46 & PA & 235 & 1.91 \\
\hline ID & 30 & 0.24 & RI & 21 & 0.17 \\
\hline IL & 470 & 3.83 & SC & 131 & 1.07 \\
\hline $\mathbb{I N}$ & 173 & 1.41 & $S D$ & 10 & 0.08 \\
\hline KS & 48 & 0.39 & $\mathrm{TN}$ & 106 & 0.86 \\
\hline KY & 31 & 0.25 & TX & 1405 & 11.44 \\
\hline LA & 89 & 0.72 & UT & 80 & 0.65 \\
\hline$M A$ & 86 & 0.70 & VA & 289 & 2.35 \\
\hline$M D$ & 291 & 2.37 & $V T$ & 4 & 0.03 \\
\hline$M E$ & 4 & 0.03 & WA & 210 & 1.71 \\
\hline $\mathrm{MI}$ & 211 & 1.72 & WI & 53 & 0.43 \\
\hline$M N$ & 107 & 0.87 & $w V$ & 9 & 0.07 \\
\hline$M O$ & 195 & 1.59 & Wr & 10 & 0.08 \\
\hline MS & 25 & 0.20 & & & \\
\hline
\end{tabular}

loans. In fact, together these three states account for approximately 53\% of all reo sales in the sample. In contrast, Alaska has only one sale.

Exhibit 3 describes each of the variables used in the empirical analysis. The first two variables are used to define the dependant variable, the foreclosure discount $(\Delta)$. The percentage house price growth of the reo sold property is denoted by $\% \Delta h p_{i s t}$, where $i$ indexes the property; $s$ the time period in which the loan was 
Exhibit 3 | Description of Variables

\begin{tabular}{|c|c|c|}
\hline Variable & Source & Description \\
\hline$\% \Delta h p i_{m s t}$ & $\begin{array}{l}\text { Office of Federal Housing } \\
\text { Enterprise Oversight } \\
\text { (OFHEO, www.ofheo.gov) }\end{array}$ & $\begin{array}{l}\text { The percentage change in metropolitan area } \\
\text { house prices from the date of origination to } \\
\text { the date the foreclosed property is sold. The } \\
\text { percentage change is expressed as a fraction } \\
\text { so that a } 95 \% \text { change is reported as } 0.95 \text {. } \\
\text { This variable is used with } \% \Delta h p_{\text {ist }} \text { to calculate } \\
\text { the foreclosure discount. }\end{array}$ \\
\hline$\% \Delta h p_{i s t}$ & Loan level data & $\begin{array}{l}\text { The percentage change in the selling price of } \\
\text { the property from the date of origination to } \\
\text { the date of sale. The percentage change is } \\
\text { expressed as a fraction so that a } 95 \% \text { change } \\
\text { is reported as } 0.95 \text {. }\end{array}$ \\
\hline$\% \Delta h p i_{m s t}-\% \Delta h p_{i s t}$ & Loan level data \& OFHEO & $\begin{array}{l}\text { The difference between the metropolitan area } \\
\text { appreciation rate and the specific property } \\
\text { appreciation rate from the date of origination } \\
\text { through sale of the property. This difference, } \\
\text { or the foreclosure discount, can be } \\
\text { interpreted as percentage point differences } \\
\text { expressed as fractions. Therefore, if the } \\
\text { foreclosure discount is reported as } 0.05 \text {, then } \\
\text { the foreclosed property appreciated } 5 \\
\text { percentage points less than the metropolitan } \\
\text { area as a whole. }\end{array}$ \\
\hline$r e o_{i t}$ & Loan level data & $\begin{array}{l}\text { The number of months that the property has } \\
\text { been owned by the lender / investor or been } \\
\text { reo (real estate owned). This time period } \\
\text { occurs after the loan has been delinquent and } \\
\text { defaulted on. The lender typically takes } \\
\text { physical possession of the property at the } \\
\text { beginning of the reo time period. The lender } \\
\text { also typically conducts maintenance to } \\
\text { prepare the property for sale and markets the } \\
\text { property for sale. }\end{array}$ \\
\hline pre-reo $_{i t}$ & Loan level data & $\begin{array}{l}\text { The age of the loan in months when the } \\
\text { default is complete and the property enters } \\
\text { reo. The complete fimeline for the property is } \\
\text { therefore represented by the variables pre-reo } \\
\text { and reo. The sum of pre-reo and reo will } \\
\text { equal the total number of months from } \\
\text { origination to sale of the foreclosed property. }\end{array}$ \\
\hline Judicial & Pence (2003) & $\begin{array}{l}\text { The loan exists in a stale with a judicial } \\
\text { foreclosure process. }\end{array}$ \\
\hline$S R R_{i}$ & Pence (2003) & $\begin{array}{l}\text { The loan exists in a state where the borrower } \\
\text { has the statutory right of redemption. }\end{array}$ \\
\hline
\end{tabular}


Exhibit 3 | (continued)

Description of Variables

\begin{tabular}{|c|c|c|}
\hline Variable & Source & Description \\
\hline nonDJ $J_{i}$ & Pence (2003) & $\begin{array}{l}\text { The loan exists in a state where the lender } \\
\text { does not have the right to declare a } \\
\text { deficiency judgment against the borrower. }\end{array}$ \\
\hline$I v_{i}$ & Loan level data & $\begin{array}{l}\text { The LTV ratio of the loan at origination, } \\
\text { expressed as a fraction. }\end{array}$ \\
\hline sato $_{i}$ & $\begin{array}{l}\text { Freddie Mac's Primary } \\
\text { Mortgage Market Survey } \\
\text { (PMMS) }\end{array}$ & $\begin{array}{l}\text { The spread at origination between the } \\
\text { contract interest rate and the market interest } \\
\text { rate on the loan divided by } 10 \text {. }\end{array}$ \\
\hline loan amount & Loan level data & $\begin{array}{l}\text { Loan amount is the dollar amount expressed } \\
\text { in } 100,000 \text { 's that was borrowed. }\end{array}$ \\
\hline
\end{tabular}

originated (the first transaction); and $t$ the time period in which the distressed property is sold. All percentages are expressed as a decimal $(5 \%=0.05)$. The $\% \Delta h p i_{m s t}$ is the percentage change in metropolitan area house prices from the origination date of the loan through the sale as measured by the metropolitan area OFHEO repeat sale house price index $;^{4} m$ indexes the location of the house in a metropolitan area. The difference between these two price appreciation variables $\left(\Delta=\% \Delta h p i_{m s t}-\% \Delta h p_{i s t}\right)$ is the discount associated with being a foreclosed property. For instance, if prices for the foreclosed property went up $10 \%$ and metropolitan area prices went up $15 \%$ for the same time period, then the discount was $5 \%$ or 0.05 . Note that the average discount, as reported in Exhibit 4, was $22 \%$ or, as shown in the descriptive statistics, 0.22 . This should be interpreted as the discount over the whole life of the loan or cumulative appreciation discount, not the discount on the transaction price.

To help identify the marginal impact of the lender's bargaining position or marketing position, the timeline of the property can be separated into two time periods: (1) the time period before the lender gains ownership of the property and (2) the time period when the lender becomes the owner and markets the property for sale. The first time period will represent the natural discount associated solely with being a foreclosure sale. The variable pre-reo $_{i t}$ is the number of months that a loan exists prior to the property entering reo. Therefore, it will capture the baseline foreclosure discount as the loan ages $(\phi)$. The second time period represents any additional deviation or discount associated with the marketing and bargaining time period. The variable reo $_{i t}$ indicates the number of months that the loan has been in the reo state (the time period when the property is owned by the lender/investor) until it is sold. As a result, it will represent the marginal impact of the lender's reo holding period on price appreciation $(\beta)$, holding all other factors constant. The expected impact for this variable is positive (a larger 
Exhibit 4 | Summary Statistics

\begin{tabular}{|c|c|c|c|c|}
\hline Variable & Mean & Std Dev & Minimum & Maximum \\
\hline$\% \Delta h p i_{m s t}-\% \Delta h p_{i s t}$ & 0.22 & 0.19 & -1.29 & 1.24 \\
\hline$r e o_{i t}$ & 5.90 & 3.57 & 0 & 30 \\
\hline$r e o_{i t} \leq 2$ & 0.15 & 0.35 & 0 & 1 \\
\hline $2<$ reo $_{i t} \leq 4$ & 0.26 & 0.44 & 0 & 1 \\
\hline $4<$ reo $_{i t} \leq 6$ & 0.24 & 0.43 & 0 & 1 \\
\hline $6<$ reo $_{i t} \leq 8$ & 0.15 & 0.36 & 0 & 1 \\
\hline $8<r e o_{i t} \leq 10$ & 0.09 & 0.29 & 0 & 1 \\
\hline $10<r e o_{i t} \leq 12$ & 0.05 & 0.22 & 0 & 1 \\
\hline $\mathrm{reo}_{i n}>12$ & 0.06 & 0.23 & 0 & 1 \\
\hline pre-reo $_{i t}$ & 27.86 & 10.68 & 4 & 57 \\
\hline pre-reo it ${ }^{2}$ & 890.16 & 631.17 & 16 & 3249 \\
\hline$\% \Delta h p i_{m s t}$ & 0.10 & 0.06 & -0.17 & 0.44 \\
\hline$\% \Delta h p i_{m s t}<0$ & 0.05 & 0.21 & 0 & 1 \\
\hline Judicial $_{i}$ & 0.42 & 0.49 & 0 & 1 \\
\hline$S R R_{i}$ & 0.06 & 0.23 & 0 & 1 \\
\hline nonDJ $_{i}$ & 0.27 & 0.44 & 0 & 1 \\
\hline Itvi & 0.93 & 0.05 & 0.36 & 1 \\
\hline sato $_{i}$ & 0.06 & 0.05 & -0.42 & 0.35 \\
\hline loan amount $t_{i}$ & 0.97 & 0.44 & 0.16 & 3.05 \\
\hline (loan amount $)^{2}$ & 1.12 & 0.97 & 0.03 & 9.28 \\
\hline \multicolumn{5}{|c|}{$\begin{array}{l}\text { Notes: The number of observations is } 12,280 \text {. In the estimation, pre-reo is divided by } 100 \text { and all } \\
\text { continuous variables are mean deleted (actual value-mean value), so that the mean value during } \\
\text { estimation is zero. } \% \Delta h p i \text { is the fractional change in house prices from the origination date of the } \\
\text { loan through the date of sale as measured by the OFHEO repeat sale house price index (hpi); } \\
\% \Delta h p \text { is the fractional change in the value of the house from loan origination through sale date; } \\
\% \Delta h p i<1 \text { is a dummy variable indicating that the metropolitan area price index has decreased; } \\
\text { reo is the number of the months the property was real estate owned until sale; pre-reo is the age } \\
\text { of the loan in months when it became owned by the investor or entered reo; Judicial indicates that } \\
\text { the loan exists in a state with a judicial foreclosure process; SRR indicates that the loan exists in a } \\
\text { state where the borrower has the statutory right of redemption; nonDJ indicates that the loan exists } \\
\text { in a state where the lender does not have the right to declare a deficiency judgment against the } \\
\text { borrower; I iv is the LTV ratio of the loan at origination; and sato is the spread at origination } \\
\text { between the contract interest rate and the market interest rate on the loan divided by } 10 \text { and the } \\
\text { loan amount expressed in } 100,000 \text { 's of dollars. }\end{array}$} \\
\hline
\end{tabular}


discount), because the longer the distressed property sits on the balance sheet, the larger losses become and the more the firm can be disciplined by the market through regulatory demands or stock price declines. This discount may also reflect the difficulty that the lender has in marketing the property due to maintenance or other considerations.

Exhibit 4 indicates that the average loan spends 5.9 months in reo and 27.9 months before entering reo. The 27.9 months will include time when the loan is current and delinquent, as well as time during the foreclosure proceedings. Note that the maximum time that any loan is observed is slightly less than 5 years, which truncates the sample so that the observed defaults are primarily defaults that occur early in a loan's life. There is a wide variation in the number of months a loan exists prior to entering reo or in reo, as well as the magnitude of the foreclosure discount. To capture the impact of other factors, which may differentially affect foreclosed property, other factors are also included $(\psi)$. These factors include measures of state level foreclosure laws, risk characteristics of the loan and local housing market conditions.

\section{Specification}

The foreclosure discount $\left(\Delta=\% \Delta h p i_{m s t}-\% \Delta h p_{i s t}\right)$ may be functionally related to the arguments in Equation 2:

$$
\Delta=\alpha_{\phi}^{\prime}(\phi)+\alpha_{\beta}^{\prime}(\beta)+\alpha_{\psi}^{\prime}(\psi)+\varepsilon_{i s t}
$$

Each symbol represents a vector of potential explanatory variables. For instance, the discount may be directly related to the time spent before entering reo $(\phi)$, the time spent in reo $(\beta)$ and other factors $(\psi) . \varepsilon_{i s t}$ is an independently normally distributed error term with a constant variance that includes all other determinants of $\Delta$ not classified elsewhere. Estimates of the parameters $\alpha_{\phi}, \alpha_{\beta}$ and $\alpha_{\psi}$ provide measures of how changes in the associated variables affect the relative appreciation rate of foreclosed property.

In the estimation, all continuous variables are mean deleted. This is to aid interpretation of the piece-wise linear estimation of the impact of time spent in reo, which proxies for the impact of the marketing and bargaining period (reo). The time spent in reo is disaggregated into 7 cohorts. No constant is reported so that the estimated coefficient for each reo time length cohort can be directly interpreted as the average discount associated with that cohort. For example, when $2<$ reo $_{i t} \leq 4$ equals 1 , this implies that a loan spends more than 2 months and up to 4 months in the reo. Otherwise $2<r e o_{i t} \leq 4$ equals 0 . The summary statistics show that the majority of loans spend less than 6 months in reo, while approximately $6 \%$ of the loans spend over a year in reo. 
To capture the impact of a loan aging, as opposed to the time spent marketing the property, the number of months that a loan exists prior to entering reo (pre$\left.r e o_{i t}\right)$ is also included. To allow for any non-linear impacts, the square of pre-reo ${ }_{i t}$ is also included. This could be thought of as representing the baseline foreclosure discount.

Beyond the timeline associated with a loan, other factors $(\psi)$ may also reduce or exaggerate any difference in appreciation rates between foreclosed property and the area-wide appreciation rate. These factors are grouped into housing $(H)$, legal $(L)$ and other mortgage $(M)$ impacts.

Housing market conditions may make it more or less difficult to dispose of distressed property. To proxy for housing market conditions, house price increases for the area as a whole are used $(H)$. If local house prices increase, it is expected that foreclosed properties will also experience an increase in prices, but not necessarily of exactly the same amount as the area-wide increase. If $\beta_{H}>0$, foreclosed property price appreciation rates receive an additional discount when house prices increase in general. The metropolitan area OFHEO repeat sales house price index is used to proxy for local area "average" or "market" house price appreciation rates (\% $\left.\% h p i_{m s t}\right)$. In addition, a dummy variable is included indicating when prices for the area as a whole have declined $\left(\% \Delta h p i_{m s t}<0\right)$. This may help to indicate whether the discount is larger or smaller in weak housing markets. ${ }^{5}$

Three variables are used to capture legal distinctions $(L)$ between jurisdictions and types of foreclosure. There is some evidence that local laws (state and county) can be capitalized into house prices (Pence, 2003; and Miceli, Munneke, Sirmans and Turnbull, 2002). This paper measures the impact of various state level legal requirements on the relative appreciation rate of foreclosed property to the areawide appreciation rate. Since these indicators will help determine the costs of terminating loans in default, they may be more directly capitalized into the value of distressed property than for normal property. Judicial ${ }_{i}$ indicates that the loan exists in a state with a judicial foreclosure process. $S R R_{i}$ indicates that the loan exists in a state where the borrower has the statutory right of redemption. nonDJ indicates that the loan exists in a state where the lender does not have the right to declare a deficiency judgment against the borrower.

Other mortgage-related explanatory variables $(M)$ may also impact the discount. If the characteristics of the borrower and the lender's identification of the risk characteristics of the borrower are related to or correlated with the propensity of the homeowner to maintain the property or the lender's bargaining power, then property appreciation rates will also be affected. To test for this effect, the spread at origination between the contract rate of the mortgage and the prevailing rate for prime fixed-rate mortgages $\left(s a t o_{i}\right)$ is included. The prevailing rate is the interest rate reported by Freddie Mac's Primary Mortgage Market Survey (PMMS) in the relevant month. An individual unable to initially obtain a low rate mortgage may possess a lower propensity to behave responsibly with respect to other obligations, including a willingness to maintain the property values. ${ }^{6} L t v_{i}$ is the loan-to-value 
ratio of the loan at origination and is included to test for any systematic relation between equity at origination (a risk proxy) and the relative appreciation rate. Loans with very high LTVs or little or no equity at origination will require a smaller decrease in house value to enter negative equity but once in negative equity, there is little incentive to maintain the property. Therefore, $l t v_{i}$ may exaggerate or depress the foreclosure discount. The loan amount $t_{i}$ expressed in 100,000 's of dollars and the loan amount ${ }_{i}^{2}$ complete the list of variables contained in the data set that also appear in Equation 3.

\section{Legal Issues and Definitions}

There is substantial variation across the country in how states treat the rights of the borrowers and lenders during the foreclosure process. Capone (1996) and Pence (2003) provide a comprehensive summary of the variations in foreclosure state laws. Following Pence's definitions, three foreclosure classifications are used in this paper: (1) 21 states require a judicial foreclosure process so that the lender must proceed through the court, while all other states allow a non-judicial procedure called power-of-sale, which is typically simpler, cheaper and quicker; (2) 9 states allow a statutory right of redemption so that up to a year after sale of the property the homeowner can redeem the property by paying the foreclosure price plus any foreclosure expenses; and (3) 9 states do not allow a deficiency judgment to be used by the lender to collect any losses on a foreclosure from the borrower's other assets.

Previous research has focused on the relationship between how much of the outstanding balance on a loan is recovered and state foreclosure loans. For example, Wood (1997) finds evidence that Fannie Mae recovery rates are higher in right of redemption states and lower in deficiency judgment states, potentially a counter-intuitive result. Overall, the econometric evidence of the relationship between foreclosure laws and recovery on sales is mixed (e.g., Clauretie, 1989; Clauretie and Herzog, 1990; Crawford and Rosenblatt, 1995; and Ciochetti, 1997).

\section{Empirical Results}

Ordinary least squares is used to estimate a model of the difference between metropolitan area appreciation rates and the specific appreciation rate of the reo property from origination through sale by the lender. This is referred to as the foreclosure discount when positive and the foreclosure premium when negative.

In general, the results show that foreclosed property tends to appreciate less than the area appreciation rate. While the previous literature focused on the level of house prices by estimating hedonic models, the results in this paper do support the findings of Shilling, Benjamin and Sirmans (1990), Forgey, Rutherford and VanBuskirk (1994) and Hardin and Wolverton (1996), who found that foreclosed property sells for less than other property, but do not support Carroll, Clauretie 
and Niell (1997), who found that foreclosed property sells for the same price as other property.

Specification I provides an estimate of the baseline discounts associated with the age of the loan until reo and the time spent in reo prior to sale of the property. Exhibit 5 shows that this baseline information captures almost $59 \%$ of the variation

Exhibit 5 | Ordinary least Squares Results

\begin{tabular}{|c|c|c|c|c|c|c|}
\hline \multirow[b]{2}{*}{ Variable } & \multicolumn{2}{|c|}{ Specification I } & \multicolumn{2}{|c|}{ Specification II } & \multicolumn{2}{|c|}{ Specification III } \\
\hline & Coeff. & t-Stat. & Coeff. & 1-Stal. & Coeff. & t-Stat. \\
\hline $\mathrm{reo}_{i t} \leq 2$ & 0.15 & 12.74 & 0.15 & 12.43 & 0.16 & 13.61 \\
\hline $2<$ reo $_{i f} \leq 4$ & 0.14 & 11.84 & 0.14 & 12.09 & 0.15 & 13.35 \\
\hline $4<r e o_{i t} \leq 6$ & 0.15 & 12.84 & 0.16 & 13.01 & 0.16 & 14.35 \\
\hline $6<r e o_{i t} \leq 8$ & 0.18 & 15.51 & 0.19 & 15.37 & 0.19 & 16.77 \\
\hline $8<r e o_{i t} \leq 10$ & 0.20 & 16.06 & 0.20 & 15.63 & 0.21 & 17.10 \\
\hline $10<$ reo $_{i t} \leq 12$ & 0.22 & 16.74 & 0.22 & 16.05 & 0.23 & 17.72 \\
\hline$r e o_{i t}>12$ & 0.25 & 18.59 & 0.24 & 17.44 & 0.25 & 19.05 \\
\hline pre-reo $_{i t}$ & -0.26 & -3.50 & -0.34 & -4.63 & -0.26 & -3.66 \\
\hline pre-reo ${ }^{2}{ }^{2}$ & 0.57 & 4.60 & 0.56 & 4.56 & 0.39 & 3.30 \\
\hline$\% \Delta h p i_{m s t}$ & & & 0.17 & 5.03 & 0.14 & 4.35 \\
\hline$\% \Delta h p i_{m s t}<0$ & & & 0.03 & 2.93 & 0.03 & 3.51 \\
\hline Judicial $_{i}$ & & & 0.03 & 7.45 & 0.03 & 7.32 \\
\hline$S R R_{i}$ & & & 0.02 & 2.93 & 0.01 & 1.55 \\
\hline nonD $J_{i}$ & & & -0.06 & -13.59 & -0.03 & -6.56 \\
\hline$I w_{i}$ & & & & & -0.23 & -7.97 \\
\hline sato $_{i}$ & & & & & 0.36 & 11.02 \\
\hline loan amount ${ }_{i}$ & & & & & -0.36 & -22.58 \\
\hline$(\text { loan amounti })^{2}$ & & & & & 0.12 & 16.85 \\
\hline Adj. $R^{2}$ & 0.587 & & 0.603 & & 0.640 & \\
\hline \multicolumn{7}{|c|}{$\begin{array}{l}\text { Notes: The dependent variable ( } \% \Delta h p i-\% \Delta h p \text { ) is defined as the difference between percentage } \\
\text { change in the value of the house prices in the location and the percentage change in the } \\
\text { foreclosed property from loan origination through sale, expressed in fractions. This can be } \\
\text { interpreted as the discount associated with foreclosed property. All continuous variables are mean } \\
\text { deleted (actual value-mean value), so that the mean value during estimation is zero. Tests to see if } \\
\text { extreme values in the dependant variable could be impacting results showed the results to be } \\
\text { robust. For example, if the top and bottom deciles are removed from the data, thus reducing the } \\
\text { sample to } 12,034 \text { and the range of the dependent variable to }-0.139 \text { to } 0.779 \text {, there is little or } \\
\text { no impact on the results. The adjusted } R^{2} \text { did increase to } 0.679 \text { and the } S R R_{i} \text { became insignificant } \\
\text { at all levels. All other coefficients changes were not material. }\end{array}$} \\
\hline
\end{tabular}

\begin{tabular}{l|l|l} 
JRER & Vol. 28 & No. 2 -2006
\end{tabular} 
in the foreclosure discount. Since all continuous variables are mean deleted, the expected discount can be read directly from the reo dummy variables. For example, using Specification I, if a loan is the average loan in all aspects accept that it spends only one month in reo, the expected discount is 15\% (as reported by the coefficient 0.15 because the dependent variable is expressed in fractions). The discount drops to $14 \%$ for a reo time period of two to four months and then steadily rises to $25 \%$ for loans that spend a year or more in reo before being sold.

By subtracting the coefficient estimate through time, the results provide estimates of the marginal impact of the loan spending more time in reo. For example, the discount increases by 3 percentage points $(0.22-0.25)$ when the time in reo increases from 12 to 13 months. This result is consistent with the hypothesis that lenders who are selling distressed property are in a weak bargaining and marketing position leading to lower than average appreciation rates. Therefore, as the property spends more time in reo, losses are increasing and the pressure to liquidate the property is mounting. In addition, the time spent may indicate difficulty in fixing any maintenance problems associated with the property, thus leading to lower than average appreciation.?

The next set of variables establishes the baseline foreclosure discount. This is the time period before the property enters reo $\left(\right.$ pre-reo $\left._{i t}\right)$. In this time period, the borrower still owns the property even though it may have been many months since any payment has been made on the loan. Therefore, this time period has no relation to the ability of the lender to market the property and the lender's bargaining position. Instead, it reflects the typical or baseline discount associated with a foreclosure on independent of the reo time period. The quadratic specification indicates a U-shaped baseline.

The smallest discount is when pre-reo ${ }_{i t}$ is just over 50 months. Therefore, loans that enter reo early in their lives have higher foreclosure discounts. For example, using Specification I, if the property spends 9 months in reo and pre-reo equals 12 months then the discount is $25.6 \%$, but by the time pre-reo equals 50 months, the discount has reduced to $17 \%$.

Since the longest time that loans are observed is for a pre-reo of 57 months, and most observations have observed pre-reo's below 50, these results primarily show that the discount tends to decrease, although at a declining rate as the pre-reo time period extends. In addition, these truncation issues make the results only relevant for relatively short lived loans and may not apply to longer lived loans.

Specifications II and III introduce other factors that could affect the foreclosure discount. The introduction of housing market conditions and legal restrictions increases the adjusted $R^{2}$ to .603 . Lastly, the introduction of other mortgage related factors in Specification III increases the adjusted $R^{2}$ to .640 .

Focusing on Specification III, the appreciation of reo sales captures $86 \%$ of metropolitan area-wide appreciation $\left(1-\beta_{\sigma_{\Delta h p}}\right)$. Also, note that in locations where overall prices have decreased, the discount is slightly larger. The impacts 
of the foreclosure laws mostly conform to prior expectations. The discount for selling foreclosed property is 3 percentage points higher when the foreclosure must use the judicial process. This is expected because the judicial process should include more administrative costs to interact with the court system. In contrast, the fact that a loan is in a state where the borrower has a statutory right to redeem the property has no additional impact on the discount. Lenders often delay the sale of reo property until the right of redemption period has passed, because it is difficult to sell without a "clean" title, but this impact is already measures by $r e o_{i t}$. States that do not allow deficiency judgments against defaulted borrowers experience discounts 3 percentage points lower. In addition, the borrower in default will benefit by continuing to maintain the property even in a negative equity, because they may still be liable for any losses suffered by the lender after sale of the property.

The introduction of loan information in Specification III again provides a series of compelling results. For example, loans with higher LTVs have lower discounts. This is consistent with the theory that borrowers with little equity require smaller declines in house values to trigger a default. The spread between the contract rate on the mortgage and the market rate at origination $\left(\right.$ sato $\left._{i}\right)$ is also systematically associated with the discount of foreclosed properties. For example, if a home buyer is paying a rate of $10 \%$ when the prevailing market rate is $8 \%$, then the discount on a foreclosed property would be $0.72 \%$ higher. This result may proxy for the behavior of the borrower during delinquency and default prior to eviction. Lastly, larger loans also have lower discounts until the loan amount reaches approximately $\$ 150,000$. After this point, the discount increases. This may reflect the higher transaction costs associated with selling a lower priced home.

\section{Conclusion}

Using metropolitan area repeat sales price indexes, this research finds evidence that foreclosed property appreciates more slowly than the area average appreciation rates. The proposed method is simple, is easy to replicate, and uses information available to any lender. Unlike the hedonic models, this approach does not require detailed information about the property itself, its neighbors, or the characteristics of the location, and can be used by lenders and investors to estimate the expected sale price of property if the borrower becomes delinquent.

While the results do not indicate that the foreclosure itself causes the price appreciation deviation, they are consistent with the notion that foreclosure proxies for other neighborhood- or property-specific characteristics, such as a neighborhood in decline.

In addition, this paper extends the literature by examining the pricing patterns of foreclosed property over the entire United States and includes a sample of over 12,000 sales of reo property. The empirical results find that foreclosed property appreciates on average $22 \%$ less than the area average appreciation rate. However, 
the magnitude of the difference or the foreclosure discount is sensitive to housing conditions, legal constraints and loan characteristics. In addition, the longer a lender owns a piece of property (real estate owned property) after default, the larger the foreclosure discount (actual minus area-wide appreciation). This result is consistent with the theory that the ability to market the property, as well as seller characteristics, can impact expected prices and, as a result, expected appreciation rates.

While this paper provides a new method of estimating the extent that foreclosed property prices are expected to deviate from area averages, one potential avenue of future research could focus on the probability of foreclosure using the characteristics of the property, location, borrower and mortgage to help account for potential selection bias.

\section{Endnotes}

1 An alternative approach not used in this paper would be to examine the sale of repeat observations where the first transaction is the sale of foreclosed or reo property and the second transaction is the sale of typical or normal property.

2 The authors indicate that future specification tests including ZIP code fixed effects did not materially affect the results.

3 The borrower can also declare bankruptcy anytime during or before the foreclosure process. The foreclosure is stayed (cancelled or at least postponed) until lifted by the bankruptcy court. The investor or lender can then file a motion for relief, which is typically granted if the outstanding mortgage is larger then the value of the house (negative equity) (Nemeth and Van Horn, 1994).

${ }^{4}$ Note that the area-wide appreciation rate used is the Office of Federal Housing Enterprise Oversight (OFHEO) metropolitan area repeat sales house price index. This price index includes all whole loan purchases by Fannie Mae and Freddie Mac (F\&F). Therefore, it includes both home purchases and refinances, as well as some foreclosed property. Given $F \& F s$ lending standards and the very low rate of $F \& F$ foreclosure, foreclosed property must be a very small fraction of the total volume of transactions. But if the existence of foreclosure and other distressed property sales does bias the OFHEO price index, it should drive the results toward finding no deviations between foreclosed sale price appreciation and the OFHEO price index appreciation.

${ }^{5}$ Note that various specifications were tested. For example, a spline function (a negative price appreciation dummy interacted with the appreciation) was tested to allow more functional form flexibility, but was statistically insignificant.

${ }^{6}$ Note that loans with interest rates 100 basis points or more above the prevailing prime rate are over-sampled. In the estimation, weighted and unweighted ordinal least squares were tested and the specification was found to be robust.

7 An alternative specification could include an intercept and dummy variables for the remaining categories. When reoit $\leq 2$ is the excluded category in Specification III, all 
categories are significant expect $4<$ reoit $\leq 6$. In other words, the marginal impact of increased time in reo is statistically significant.

\section{References}

Arnold, M., Search, Bargaining and Optimal Asking Prices, Real Estate Economics, 1999, 27:3: 453-81.

Capone, Jr. C. A., Providing Alternatives to Mortgage Foreclosure: A Report to Congress, Washington, D.C.: United States Department of Housing and Urban Development, 1996.

Carroll, T., T. Clauritie and H. Neill, Effect of Foreclosure Status on Residential Selling Price: Comment, Journal of Real Estate Research, 1997, 13:1, 95-102.

Ciochetti, B. A., Loss Characteristics of Commercial Mortgage Foreclosure, Real Estate Finance, 1997, 14:1, 53-69.

Clauretie, T. M., State Foreclosure Laws, Risk Shifting, and the PMI Industry, Journal of Risk and Insurance, 1989, 56:3, 544-54.

Clauretie, T. M. and T. Herzog, The Effect of State Foreclosure Laws on Loan Losses: Evidence from the Mortgage Insurance Industry, Journal of Money, Credit and Banking, 1990, 22:2, 221-33.

Crawford, G. W. and E. Rosenblatt, Efficient Mortgage Default Option Exercise: Evidence from Loss Severity, Journal of Real Estate Research, 1995, 10:5, 543-55.

Downs, A., Who's Running U.S. Banks Anyway?, National Real Estate Investor, 1992, 34:6, $22-4$.

Forgey, F., R. Rutherford and M. VanBuskirk, Effect of Foreclosure Status on Residential Selling Price, Journal of Real Estate Research, 1994, 9:3, 313-18.

Genesove, D. and C. Mayer, Equity and Time to Sale in the Real Estate Market, American Economic Review, 1997, 87:3, 255-69.

Harding, J., T. Miceli and C. F. Sirmans, Do Owners Take Better Care of their Housing than Renters, Real Estate Economics, 2000, 28:4, 663-81.

Harding, J., S. Rosenthal and C. F. Sirmans, Estimating Bargaining Power in the Market for Existing Homes, Review of Economics and Statistics, 2003, 85:1, 178-88.

Hardin, W. and M. Wolverton, The Relationship Between Foreclosure Status and Apartment Price, Journal of Real Estate Research, 1996, 12:1, 101-09.

Nemeth, C., P. and G. P. Van Horn, Real Estate Foreclosure: Paralegal Practice and Procedure, New York, NY: Wiley Law Publications, John Wiley \& Sons, Inc., 1994.

McQueen, G. and B. Slade, Do Out-of-State Buyers Pay More for Real Estate? An Estimation of Anchoring-Inducing Bias and Search Cost, Paper presented at the American Real Estate and Urban Economics Association International Conference, 2003.

Miceli, T., H. Munneke, C. F. Sirmans and G. Turnbull, Title Systems and Land Values, Journal of Law and Economics, 2002, 45:2, 565-82.

Palmer, J., Great Performers and Bad Actors, Barron's, October 7, 1991, 14-5.

Pence, K. M., Foreclosing on Opportunity: State Laws and Mortgage Credit, Paper presented at the Allied Social Science Association Conference in the American Real Estate and Urban Economics Association Session, January, 2003.

Shilling, J., J. Benjamin and C. F. Sirmans, Estimating Net Realizable Value for Distressed Real Estate, Journal of Real Estate Research, 1990, 5:1, 129-40. 
Turnbull, G., and C. F. Sirmans, Information, Search, and House Prices, Regional Science and Urban Economics, 1993, 23:4, 545-57.

Watkins, D., Are New Entrants to the Residential Property Market Informational Disadvantaged? Journal of Property Research, 1998, 15(1), 57-70.

Wood, C., The Impact of Mortgage Foreclosure Laws on Secondary Market Loan Losses, Ph.D. Thesis, Cornell University, 1997.

The views expressed in this research are those of the author and do not necessarily reflect the official positions of the Federal Reserve Bank of St. Louis, the Federal Reserve System, and the Board of Governors. I would like to thank Tom Lutton for his guidance and support and the referees for their insightful and helpful comments, which greatly improved the paper. 